\title{
PRZEMIANY EMOCJONALNOŚCI W PROCESIE REWOLUCJI KONSUMPCYJNEJ
}

\section{Joanna Zalewska*}

\begin{abstract}
Abstrakt
Celem artykułu jest analiza przemian emocjonalności w procesie rewolucji konsumpcyjnej, w kontekście polskim w środowisku wielkomiejskim. Wyodrębniono dwa typy emocjonalności: emocjonalność wpisaną w dyskurs postępu oraz nowoczesny hedonizm. Na podstawie etnograficznych badań terenowych, poddano analizie emocje wobec udomawianych technologii. Dyskurs postępu dominuje wśród rozmówców ze starszych pokoleń, nowoczesny hedonizm w najmłodszym pokoleniu transformacji. Przemiany emocjonalności to: wzrost emocjonalności, czyli częstsze wyrażanie emocji oraz większa liczba i zróżnicowanie wyrażanych emocji; wyrażanie emocji pożądania; angażowanie się w praktyki dla wzbudzenia emocji.
\end{abstract}

Słowa kluczowe: dyskurs postępu, emocje, nowoczesny hedonizm, pokolenie historyczne, rewolucja konsumpcyjna, udomowienie technologii

\section{CHANGES IN EMOTIONALITY THROUGHOUT CONSUMER REVOLUTION}

\begin{abstract}
This article discusses changes in emotionality throughout the consumer revolution in urban contexts in Poland. There are two types of emotionality: emotionality imbedded in discourse of progress; and modern hedonism. Drawing upon ethnographic data, emotions towards domesticated technologies were analyzed. Discourse of progress dominates among informants from older historical generations, modern hedonism dominates among the generation of transformation. The changes in emotionality: increase in emotionality, which means more often expression of emotions and larger number and diversity in expressed emotions; expressing the emotion of desire; engaging in practices with the goal of raising emotions through these practices.
\end{abstract}

Keywords: Consumer revolution, discourse of progress, domestication of technology, emotions, historical generation, modernity, modern hedonism, progress

*Dr hab. Joanna Zalewska, prof. APS, Akademia Pedagogiki Specjalnej im. Marii Grzegorzewskiej, Warszawa, Polska | e-mail: joanna.marta.zalewska@gmail.com | ORCID: https://orcid.org/ 0000-0002-2605-669X 
Pojęcie rewolucji konsumpcyjnej stosowane jest do zrozumienia przemian prowadzących do powstania nowoczesnych społeczeństw konsumpcyjnych. Odnosi do znacznego wzrostu wydatków gospodarstw domowych na dobra produkowane przemysłowo i rozwoju wymiany rynkowej opartej na gospodarce pieniężnej. J est to przejście od gospodarki naturalnej do gospodarki rynkowej. Pierwszą rewolucję konsumpcyjną odnotowano w Anglii w drugiej połowie XVIII wieku, kiedy w ciągu pięciu dekad wydatki gospodarstw domowych wzrosły o 370\% (McKendrick, Brewer, Plumb 1982). W ten sposób definiowane jest pojęcie rewolucji konsumpcyjnej z perspektywy ekonomicznej. Zdaniem Neila McKendricka waga tej rewolucji była porównywalna z doniosłością rewolucji neolitycznej, w tak diametralny sposób zmieniała warunki i sposób życia ludzi na przestrzeni kilku dekad (por. Zalewska 2013).

Definicja socjologiczna rewolucji konsumpcyjnej różni się od definicji w kategoriach ekonomicznych. Rewolucja konsumpcyjna rozumiana jest tu jako przemiana społecznie zorganizowanych form konsumpcji: od tych właściwych dla społeczeństw tradycyjnych (zakaz) i feudalnych (norma regulatywna) w kierunku nowoczesnej formy konsumpcji, czyli mody opartej na społecznym naśladownictwie (social emulation). Zakaz obowiązuje w małych, rytualnie zorientowanych społeczeństwach, dysponujących prostymi technologiami. Organizuje konsumpcję za pomocą listy rzeczy, które należy i których nie należy robić w zależności od kontekstu czasowego i przynależności do kategorii społecznej. Zakazy są ściśle związane ze sferą religijną lub kosmologiczną danej społeczności. Norma regulatywna charakterystyczna dla Europy w okresie feudalnym, polegała na tym, żena podstawieprawa zwyczajowego pewnerodzaje dóbr, np. tkanin, przypisane były określonym warstwom społecznym. Przemiana w kierunku mody jako nowoczesnej formy konsumpcji zachodziła pod postacią strumienia zdarzeń nazywanych rewolucją konsumpcyjną (Appadurai 2005). Do tych zdarzeń, czyli czynników 
rewolucji konsumpcyjnej, zaliczano: rewolucję przemysłową i nową w dziejach wysoką podaż dóbr konsumpcyjnych, wyprodukowanych przemysłowo; względną zamożność dużej części społeczeństwa; rozwój marketingu i technik sprzedażowych (McKendrick, Brewer, Plumb 1982), a dodatkowo czynników związanych z rozwojem szeroko rozumianej nowoczesności - mobilność społeczną, konflikt klasowy, znajomość pisma i rachunków, wiedzę ekspercką handel książkami, inne formy skomercjalizowanej informacji (Appadurai 2005).

J ak pokazuje Colin Campbell (1987), żaden z wymienionych czynników nie wyjaśnia nienasycenia nowoczesnego konsumenta, związanego z podstawową cechą nowoczesnej mody - jej ciągłej i szyblkiej zmienności. Campbell upatruje genezy nowoczesnego konsumpcjonizmu i rządów mody w przemianie struktury psychicznej jednostek, a precyzyjniej miejsca emocji w tej strukturze oraz sposobów doświadczania i kontrolowania emocji. Badacz dokonuje analizy psychogenezy nowoczesnego podmiotu, podobnie jak Norbert Elias w pracy $O$ procesie cywilizacji (2011), przy czym Elias analizuje okres trochę wcześniejszy i warstwę arystokracji przede wszystkim we Francji, zaś Campbell wiek XVII i XVIII oraz warstwę burżuazji w Anglii. Wywód Campbella pozwala zrozumieć, jak ukształtowała się nowoczesna jednostka: jej charakter społeczny z trzema najbardziej rozpowszechnionymi cechami - egotyzmem, emocjonalnością, ontologiczną niepewnością (Marody 2014) oraz kierowanie się emocjami przy dokonywaniu życiowych wyborówujęte w pojęciu podmiotu emocjonalnego (Zalewska 2014: idem 2015).

Pojęcie rewolucji konsumpcyjnej jest stosowane do rozumienia przemian zachodzących w drugiej połowie XX wieku w Polsce. Z perspektywy ekonomicznej mieliśmy do czynienia z odejściem od gospodarki naturalnej, rewolucyjnym, bowiem skala tego przejścia, jeśli porównamy społeczeństwo przedwojenne i społeczeństwo lat 60. XX wieku, była ogromna. Odejście od gospodarki naturalnej wiązało się z powojenną tzw. drugą rewolucją przemysłową (Davies 2005). Duże znaczenie miały mobilność społeczna i rozwój gospodarki pieniężnej. Obydwa te 
czynniki miały związek z intensywnym uprzemysłowieniem i odbudową kraju po wojnie. Ogromne migracje wewnętrzne charakteryzowały okres powojenny. Głównie były to migracje ze wsi do miast, duża część ludności chłopskiej migrowała, znajdując zatrudnienie w uprzemysławiających się szybko w tym okresie miastach. Przed wojną w 1938 roku $70 \%$ populacji zamieszkiwało wsie, były to samowystarczalne gospodarstwa w bardzo niewielkim stopniu uczestniczące w gospodarce pieniężnej. Przedwojenni chłopi posiadali niewielki wolumen pieniądza i transakcje gotówkowe stanowiły małą część ich gospodarowania. Rodzina była jednostką produkcyjną. Po wojnie $(1946,1949)$ dwie trzecie mieszkańców Polski zamieszkiwało wsie, natomiast w 1967 roku już ponad 50\% ludności mieszkało w miastach (Okólski 2002).

Te procesy wiązały się z gruntowną przemianą sposobu życia, którą Marcin Czerwiński (1969) ujmuje za pomocą pojęcia rewolucji obyczajowej, która dokonała się do lat 60 . XX wieku. Wjej ramach zamieszcza odejście od gospodarki naturalnej. Nazywa to „wyjściem” funkcji produkcyjnej z rodziny, w rodzinie pozostaje jedynie organizacja konsumpcji, również uproszczona $\mathrm{w}$ porównaniu do tradycyjnej ze względu na wkraczanie infrastruktury technologicznej do gospodarstw domowych, ułatwiających organizację konsumpcji (np. prąd, woda bieżąca, pralka) oraz punkty usług zbiorowych, takie jak sklepy. J eśli porównamy lata 50. z latami 30. XX wieku, to mamy do czynienia z podwojeniem spożycia żywności luksusowej, a więc cukru oraz mięsa (GUS 1956), wzrost spożycia dotyczył głównie ludności rolniczej i ludności migrującej ze wsi do miast (Pohoski 1963). J ednakże, druga rewolucja przemysłowa w Polsce charakteryzowała się niedoinwestowaniem sektora dóbr konsumpcyjnych (Davies 2005). Ze względu na ustawicznie powtarzające się w okresie PRL-u niedobory dóbr konsumpcyjnych, pojawiła się konieczność częściowej renaturalizacji konsumpcji, a rewolucja konsumpcyjna wznaczeniu ekonomicznym została zahamowana. Tym niemniej, w trakcie tych przemian większość Polaków zaczęła uczestniczyć w szerszym systemie gospodarczym, nawet 
jeśli system ten był wadliwy i była konieczność zaspokajania wielu potrzeb poza tym systemem.

J eśli chodzi o rewolucję konsumpcyjną w znaczeniu socjologicznym, Czerwiński (1969) już w latach 60. poprzedniego wieku w warunkach miejskich zaobserwował dominację środowisk koleżeńskich jako grupy odniesienia normatywnego przy spadku autorytetu rodzin i starszych. Doniesienia z badań etnograficznych również prowadzone w miastach wskazują, że - pomimo niedoborów na rynku dóbr - rewolucja konsumpcyjna w znaczeniu socjologicznym, czyli mechanizm mody oparty na społecznym naśladownictwie i aspiracje do konsumpcji ukształtowały się do końca lat 60 . XX wieku i niemałą rolę odegrało w tym procesie upowszechnienie się telewizji (Zalewska 2017; idem 2018). Zostało to zaobserwowane również przez ówczesnych badaczy stylów życia Leona Dyczewskiego (1982) oraz Markku Haranne i Andrzeja Sicińskiego (1987), którzy pisali o masowym czy naśladowczym stylu życia.

Według Campbella dla ukształtowania się nowoczesnej konsumpcji, konieczna jest przemiana emocjonalności. Czy w warunkach polskich również się ona dokonała? Celem artykułu jest odpowiedź na pytanie badawcze: czy przemiany emocjonalności następowały w procesierewolucji konsumpcyjnej w kontekście polskim w środowisku wielkomiejskim¹. Badania przeprowadzono w wielkich miastach ze względu na to, że spodziewano się, że środowisko wielkomiejskie sprzyja nowoczesnej konsumpcji, a przemiany będą tam zachodzić w sposób bardziej intensywny niż w mniejszych ośrodkach. Poniżej poddam analizie emocje pojawiające się w trakcie procesu udomowienia technologii (domestication of technology), czyli kluczowego czynnika rewolucji konsumpcyjnej w Polsce. Studia nad udomowieniem technologii zrodziły się w obszarze

\footnotetext{
${ }^{1}$ Dotychczasowe wyniki badań nad polskim społeczeństwem pokazują, że zachodzące zmiany społeczne wiążą się z przemianami emocjonalności. Wykazano, że w okresie transformacji ustrojowej nastąpiło przejście od zarządzania opartego na autorytecie, patriarchalnego do bardziej partnerskiego, zarówno w sferze rodzinnej, jak i zawodowej, co wymaga odmiennej kontroli emocji (Sawicka, Sikorska 2020).
} 
antropologii konsumpcji w ramach tzw. zwrotu w kierunku przedmiotów w naukach społecznych. Udomowienie jest procesem, w ramach którego dana technologia wkracza do gospodarstwa domowego jako przedmiot, ale również nośnik sfery publicznej i zostaje zaadaptowana do rutyny codziennych praktyk i struktury przestrzeni domu (Skowrońska 2020). W XVIII-wiecznej Anglii domowe technologie jeszcze nie istniały, a gdy wkraczały, były przyjmowane przez spragnionego nowości i zawsze nienasyconego nowoczesnego konsumenta. Z kolei w Polsce stały się jednymi z pierwszych obiektów, wobec których uzasadnionym było otwarciesię na nowość, zaś uzasadnienie to dawał dyskurs postępu (Zalewska 2017; idem 2020).

Rozpocznę od scharakteryzowania - na podstawie literatury przedmiotu - nowoczesnego hedonizmu i dyskursu postępu, z którymi wiążą się odmienne typy emocjonalności i które zakładają odmienny stosunek emocjonalny wobec technologii wkraczających w życie codzienne. Następnie poddam analizie materiał pochodzący z 28 retrospektywnych wywiadów pogłębionych, w tym 24 wywiadów z diadami i czterech wywiadów indywidualnych, przeprowadzonych w Warszawie i Poznaniu z przedstawicielami kilku pokoleń historycznych ${ }^{2}$. Wyodrębnię kategorie, na podstawie których porównywane będą dwa typy emocjonalności, a następnie przedstawię, jaki stosunek emocjonalny do technologii wiąże się z tymi dwoma typami emocjonalności. Na koniec sprawdzę, czy w ramach grupy badanej są różnice pokoleniowe, jeśli chodzi o występowanie tych dwóch typów emocjonalności.

2 Badania były finansowane w ramach grantu Narodowego Centrum Nauki, projekt nr 2014/15/D/ HS6/04811 "Rewolucja konsumpcyjna w Polsce". 
Od tradycyjnego do nowoczesnego hedonizmu: podmiot emocjonalny u Colina Campbella

Campbell rozgranicza dwie podstawowe motywacje ludzkich zachowań, jeśli chodzi o konsumpcję: zaspakajanie potrzeb (needs) oraz poszukiwanie przyjemności (pleasure seeking), inaczej zaspakajanie pragnień (desires, wants). Zauważa jednakże, że rozdzielenie to ma charakter czysto teoretyczny, a w doświadczeniu są one nierozdzielne w społeczeństwach / warstwach społecznych, w których życie jest walką o przetrwanie, a zaspokajanie potrzeb jest niepewne, niestabilne i nieregularne. W takiej sytuacji zaspokojenie potrzeby daje również przyjemność: najedzenie się w sytuacji, gdy następuje to nieregularnie i zdarza się, że jednostka głoduje, wiąże się z doświadczeniem przyjemności. W historii, w wielu społeczeństwach pojawiały się uprzywilejowane warstwy i grupy, które miały możliwość w sposób stabilny i regularny zaspokajać swoje potrzeby. Natomiast w nowoczesności stabilność i regularność zaspokajania potrzeb dotyczy znacznej większości społeczeństwa. Ze względu na stabilność i regulamość zaspakajania potrzeb, moment zaspokojenia potrzeb stracił możliwość wzbudzenia doznania przyjemności. Kiedy jada się regularnie posiłki i nie odczuwa głodu, kolejne napelnienie żołądka przestaje dawać zmysłową przyjemność. W życiu pojawia się deficyt przyjemności, staje się nudnei mało ekscytujące.

W takiej sytuacji kształtują się zachowania ukierunkowane na poszukiwanie przyjemności, bowiem samo zaspokajanie potrzeb, nie wystarczajuż, by wzniecić doznanie przyjemności. Tutaj pojawia się tytułowe dla tego podrozdziału rozróżnienie: poszukiwanie przyjemności jest odmienne w społeczeństwach tradycyjnych i nowoczesnych, Campbell nazywa je tradycyjnym i nowoczesnym hedonizmem. Tradycyjny hedonizm ukształtował się w warstwach uprzywilejowanych społeczeństw tradycyjnych. Polegał na pogoni za zmysłowymi przyjemnościami. Przyjemności traktowano jako odrębne wydarzenia: uczty, bale, turnieje. 
Niestety tak rozumiane zmysłowe przyjemności z czasem nudziły się, im więcej przyjemności, tym słabsze każda kolejna przynosiła doznania.

Nowoczesny hedonizm zdaniem Campbella opiera się na innym mechanizmie. Nowoczesny człowiek nie goni za zmysłowymi przyjemnościami. On wytwarza przyjemność za pomocą wyobraźni, dodaje element przyjemności do każdego codziennego doświadczenia. Ten aspekt przyjemności daje odczuwanie emocji w każdym doświadczeniu. Czyli w tradycyjnym hedonizmie przyjemność dawały zmysły, zaś wnowoczesnym emocje. Ażeby czerpać przyjemność z emocji, muszą one być znacznie bardziej obrobione i kontrolowane niż to ma miejsce w większości kultur. W każdym społeczeństwie, pewne zdarzenia i sytuacje mają przypisane pewne emocjonalne znaczenia, zaś inne emocje należy w nich kontrolować - w znaczeniu dokonać ich supresji (Hochschild 2009). W nowoczesności doszło do wyjątkowej w dziejach racjonalizacji emocji: emocje automatycznie nie prowadzą do działania, tylko stają się przedmiotem procesów myślowych - strumienia świadomości, a podmiot się nimi delektuje, werbalizuje lub je analizuje - np. w procesie psychoanalizy (Illouz 2010). Campbell twierdzi, że emocje wykorzystywane w nowoczesnym hedonizmie muszą być słabsze - częściowo pozbawione swojej siły, by móc dawać przyjemność; oraz że podmiot nimi w miarę świadomie manipuluje, przypisuje je do różnych doświadczeń i do tego właśnie wykorzystywana jest wyobraźnia.

Najbardziej sztandarowym przykładem nowoczesnego hedonizmu jest zdaniem Campbella marzenie na jawie (daydreaming). Polega na wyobrażaniu sobie sytuacji, które stymulują przyjemne emocje: np. marzenie na jawie o tym, że „Ja” bohatersko ratuje ukochaną z opresji emocja dumy, radości, samozadowolenia, miłości. Na tym mechanizmie zdaniem Campbella bazują kampanie reklamowei wartość dodana produktu - umożliwia ona uzyskanie przyjemności na bazie odczuwania przyjemnych emocji. Marzenie najawiejest tym bardziej przyjemne, jeśli dotyczy realnych wydarzeń, które mają wystąpić w niedługiej przyszłości lub jest kontynuacją faktycznych przeszłych sytuacji. Niestety, 
jak twierdzi Campbell, o ile w tradycyjnym hedonizmie kolejne zmysłowe przyjemności przynoszą coraz słabsze doznania; o tyle w nowoczesnym hedonizmie rzeczywistość nigdy nie wzbudza tak przyjemnych emocji, jak marzenia na jawie - wyobrażanie sobie i oczekiwanie na przyjemne sytuacje. To dlatego nowoczesny konsument jest nienasycony i zawsze otwarty na nowe produkty oraz doświadczenia, żeby przy ich pomocy marzyć i odczuwać przyjemne emocje. Gdy znów w sytuacjach rzeczywistych interakcji nie udaje się wzbudzić tak przyjemnych emocji jak w marzeniach, konsument przenosi te nadzieje na nowy produkt.

Campbell, idąc w ślady Maxa Webera (2011), prześledził genezę nowoczesnej racjonalizacji emocji, jednakże punktem koncentracji uwagi nie były dla niego przedsiębiorczość i praca, a druga strona medalu, czyli konsumpcja. Znów miejscem powstania nowoczesnej racjonalizacji emocji była warstwa burżuazji wyznająca protestantyzm. Campbell analizuje rozwój myśli i odłamy protestantyzmu zaczynając od miejsca, w którym Weber skończył swoją pracę, czyli zajmuje się drugą połową XVII wieku i XVIII wiekiem. Zwraca uwagę, że poszukiwanie przyjemności dla samych przyjemności było potępiane, dlatego w warstwie burżuazji nastąpił zmierzch tradycyjnego hedonizmu. Następnie wskazuje, że angielscy protestanci byli bardzo wyczuleni na dowody łaski boskiej i wśród tych dowodów bardzo ważną rolę odgrywały odczuwane emocje, z jednej strony życzliwość, dobrotliwość, łaskawość (benevolence) wobec bliźniego, a z drugiej niepokój egzystencjalny, użalanie się nad sobą (self-pity), emocje związane z niepokojem i pragnieniem, by być wybranym i obdarzonym łaską boską.

Ta kontemplacja emocji, najpierw obowiązująca w sferze religijnej, w okresie sentymentalizmu została przeniesiona do sfery świeckiej. Wraz z postępem sekularyzacji wśród burżuazji i Weberowskim odczarowaniem świata (disenchantment), emocje te straciły również na pierwotnej sile. W okresie sentymentalizmu wrażliwość (sensibility) stała się cnotą, polegała na nieskrępowanej ekspresji odczuwanych emocji. 
Campbell cytuje również określenia z tego okresu wskazujące, że ówczesni ludzie znajdowali przyjemność w oddawaniu się emocjom, także tym negatywnym. Tłumaczy to w ten sposób, że protestanci dla świadomości kruchości bytu byli zobowiązani do myślenia o cmentarzach, grobach, czaszkach, itp. W tamtym czasie budziło to faktyczną grozę. J ednakże wraz z upływem czasu i osłabieniem protestanckiego światopoglądu, obrazy te przestały budzić grozę, ale nadal kojarzyły się z emocjami strachu i lęku, jednak już na niższym poziomie - odczuwanego dreszczyku na karku. J ednostka zdobyła w ten sposób władzę nad swoimi emocjami, dla zabawy mogła wyobrazić sobie te symbole przemijania i odczuwać przyjemne emocje w sposób kontrolowany, czyli dreszczyk strachu (thrill). Uczony wyjaśnia, że w ten sposób powstało upodobanie do horrorówi powieści gotyckiej. Ogromną rolę w kształtowaniu nowoczesnego hedonizmu miało czytelnictwo powieści oraz kontemplacja sztuki.

Z sentymentalizmu i myśli oświeceniowej wyrósł romantyzm, w ramach którego krytykowano sentymentalizm jako wrażliwość na pokaz. Wedle Campbella to w romantyzmie ukształtowało się poczucie odrębności pomiędzy wnętrzem człowieka a społecznym otoczeniem. Romantyk posiada emocjonalne wnętrze, które pragnie w sposób spontaniczny wyrażać. Czuje się ograniczony przez utylitarne społeczeństwo i nieusatysfakcjonowany z powodu rutynowej egzystencji w zewnętrznym świecie, co wzmacnia tendencje do marzenia na jawie. Tak więc kwestia kreowania przyjemnych emocji za pomocą wyobraźni łączy się również z kwestią tożsamości. Na podstawie pracy Campbella możemy wyciągnąć wniosek, że podmiot emocjonalny to podmiot romantyczny.

Kilka lat po wydaniu książki Campbella niemiecki socjolog Gerhard Schulze (za: Sieradzki 2007) przedstawił teorię bardzo podobną do teorii nowoczesnego hedonizmu, nazwał ją teorią społeczeństwa doznań. Takjak nowoczesny hedonizm ma być charakterystyczny dla nowoczesności, tak u Schulzego orientacja na poszukiwanie doznań ma być charakterystyczna 
dla społeczeństwa dobrobytu. Tak jak Campbell rozróżnia zaspokajanie potrzeb i poszukiwanie przyjemności, podobnie Schulze rozróżnia orientację na przetrwanie i orientację doznaniową. U Schulzego nie ma podziału analogicznego do tego na tradycyjny i nowoczesny hedonizm, poszukiwanie przyjemności w społeczeństwie dobrobytu nie różni się od tego, któremu oddawały się warstwy uprzywilejowane w mniej zamożnych społeczeństwach. J ednakże Schulze również wskazuje na wyjątkową rolę emocji worientacji doznaniowej: jednostka podejmuje działania dla wzbudzenia w sobie określonych emocji, tak samo jak w nowoczesnym hedonizmie Campbella. Podobniejak u Campbella, wspołeczeństwie doznań nie chodzi o nowy stosunek tylko do dóbr konsumpcyjnych, zmienia się całokształt stosunku wobec świata. Schulze zweryfikował swoją teorię w badaniach reprezentatywnych dla mieszkańców zachodnioniemieckiego miasta Norymbergii (ibidem).

Dyskurs postępu i udomowienie technologii w Polsce Ludowej

Dotychczasowe analizy materiałów zebranych na temat rewolucji konsumpcyjnej wPolsce wskazują, że to dyskurs postępu był pierwszym impulsem do otwierania nawyków na nowość: na nowe przedmioty i związane z nimi nowe zachowania - do wyuczenia zanim staną się rutynowe (Zalewska 2015; idem 2017; idem 2020). Idea postępu zakłada pojęcie liniowego czasu, przy czym postęp jest to pozytywnie wartościowana różnica między przeszłością a teraźniejszością (postęp dokonany) lub teraźniejszością a przyszłością (postęp przewidywany). Postęp zawiera pojęcie poprawy, rozwoju, ulepszenia (Sztompka 2010). Jako dyskurs postępu określany jest system tworzenia wiedzy zaadaptowany przez socjalistyczne państwo polskie z dyskursu naukowego (Zalewska 2020). Pojęcie to opiera się na koncepcji dyskursu Michela Foucault (1977), w ramach której dyskurs ustanawia własne zasady łączące język z rzeczywistością. Wytwarza obiekty, do których się odnosi. Za pomocą dyskursu postępu socjalistyczne państwo polskie aktywnie konstruowało 
rzeczywistość w kategoriach ciągłej zmiany, wartościowanej pozytywnie. Dyskurs postępu angażował nie tylko sferę poznawczą jednostek, ale również emocjonalną, wartościowanie wiąże się z nadawaniem pewnego znaczenia emocjonalnego obiektowi. Tak więc w dyskurs postępu wpisany był pewien typ emocjonalności, mianowicie pozytywny stosunek wobec ciągłego rozwoju, poprawy, ulepszania.

Ten aspekt ciągłej zmiany to punkt styczny dyskursu postępu i nowoczesnego hedonizmu. Natomiast motywacja do tej ciągłej zmiany jest odmienna. Uzasadnieniem dla zmiany w nowoczesnym hedonizmiejest chęć wzbudzenia emocji i odczucia przyjemności. Podmiot kierujący się taką motywacją jest podmiotem emocjonalnym, ukształtowanym w pełni dzięki nurtowi romantyzmu. Kenneth Gergen (2009) nazywa osobowość kierującą się emocjami J a romantycznym. Dla odmiany, celem zmian w dyskursie postępu jest uzyskanie wyższej jakości życia, którą da się racjonalnie zmierzyć. Taką postawę badacz przypisuje J a modernistycznemu, edukowanemu wramach narracji postępu, w pełni ukształtowanemu w pierwszej połowie XX wieku, ze względu na wkroczenie zaawansowanych technologii w życie społeczne, będących dla ówczesnych ludzi ucieleśnieniem idei postępu.

Technologie wkraczały w tym okresie również w życie codzienne, proces ten jest nazywany udomowieniem technologii. Udomowienie konkretnej technologii obejmuje jej nabycie czy uzyskanie w gospodarstwie domowym, proces umiejscawianiajej w przestrzeni domowej i sieci relacji z domownikami, infrastrukturą i innymi przedmiotami, a następnie proces wszelkich zmian w ramach tych relacji, włącznie z dołączaniem kolejnych „partnerów” w sieci relacji (Skowrońska 2020). Tak więc proces udomowienia danej technologii właściwie nigdy się nie kończy (Hand, Shove 2007) i w każdym gospodarstwie dla każdej technologii ma specyficzną, właściwą tylko tej sieci relacji formę (Silverstone 1993). Udomowienie technologii na masową skalę miało miejsce najpierw w USA, właśnie w pierwszej połowie XX wieku (Cowan 1976). W Europie na 
masową skalę zaczęło się po II wojnie światowej (De Grazia 2005). Polska nie była na tym tle wyjątkiem.

Dyskurs postępu był dla obywateli podstawowym znaczeniem udomowienia technologii, który umożliwiał, zachęcał i przymuszał do adaptacji technologii. Poprzez 1) zmiany infrastrukturalne wprowadzane w nowym budownictwie (łazienki, kuchenki gazowe, ciepła woda, elektryczność); 2) mechanizm podaży, np. nagradzanie za produktywność talonami na pralki, samochody, telewizory; 3) propagowanie postępu w czasopismach, zakładach pracy, świetlicach, domach kultury - dyskurs postępu inkorporował wszystkich obywateli, którzy poddawali się bardziej lub mniej chętnie $^{3}$ praktykom udomowienia technologii (Zalewska 2020). Udomowienie technologii z kolei zmieniało codzienne praktyki (idem 2011), uwalniając je spod władzy norm obyczajowych, a poddając rządom mody. W ten sposób pranie z czynności kobiet w gospodarstwie domowym stało się praktyką rodzinną podczas obsługi pralki Frani, a następnie wykonywaną indywidualnie w pralce automatycznej (idem 2017). Z kolei udomowienie telewizora odegrało dużą rolę w przekształceniu tradycyjnego wystroju mieszkania, w przestrzeń poddaną ciągłej zmianie podyktowanej modą (idem 2018). Analiza materiałów z badań nad stylami życia gromadzona przez zespół Andrzeja Sicińskiego na przełomie lat 70. i 80. XX wieku wkilku miastach różnego rzędu wielkości wskazuje, żeto modajako społeczne naśladownictwo była dominującym mechanizmem jeśli chodzi o decyzje na temat wyposażenia mieszkania (Zalewska, J ewdokimow - wdruku).

Dotychczasowe badania wskazują na obecność nowoczesnego hedonizmu jako modelu zapożyczonego z krajów zachodnich (Zalewska 2017). Chodzi tu o to, że w okresie PRL-u pewne zachodnie dobra konsumpcyjne urastały do rangi symbolu lepszego życia, były to np. coca-cola czy guma do żucia (Kurz 2008). Zgodnie z modelem nowoczesnego hedonizmu o tych dobrach marzono, wyobrażano sobie ich użycie (Zalewska 2017). Do tej kategorii należały również codzienne technologie, takie jak samochód,

3 Opór wobec udomawiania technologii w kontekście polskim analizuje Marta Skowrońska (2020). 
telewizor czy pralka automatyczna, tzw. automat. Realizacja tych pragnień równiė̇ często wiązała się z rozczarowaniem, ale nie jest do końca jasne, czy jest to zgodne z modelem nowoczesnego hedonizmu czy wynika z ograniczeń socjalistycznej gospodarki scentralizowanej, bowiem respondenci wskazywali głównie na niedostateczną jakość produktu (psujące się samochody), a jakość ta była porównywana z jakością produktów zachodnich (ibidem). I tutaj pojawia się dominująca rola masmediów w upowszechnianiu tego modelu emocjonalności: telewizja polska w latach 60. pokazywała dużo zachodnich filmów, dopiero w latach 70. zaczęto je cenzurować (Pleskot 2007), istniały też czasopisma, których celem było ucywilizowanie i unowocześnienie Polaków na podstawie wzorów zachodnich, na czele z „Przekrojem” (J aworska 2008).

Na podstawie literatury przedmiotu można więc wyodrębnić dwa typy emocjonalności obecne w procesie rewolucji konsumpcyjnej: typ emocjonalności wpisany w dyskurs postępu i nowoczesny hedonizm. Dyskurs postępu zaliczany jest do podstawowych czynników powojennego wybuchu rewolucji konsumpcyjnej. Kształtowanie się nowoczesnego hedonizmu łączy się z upowszechnianiem telewizji w latach 60. XX wieku. Ażeby odpowiedzieć na pytanie o przemiany emocjonalności, zobaczmy, jakie charakterystyki mają obydwa typy emocjonalności na gruncie rodzimym oraz czy można mówić o przemianach czy o współwystępowaniu.

\section{Metodologia badań}

Badania zostały przeprowadzone wlatach 2018-2019 w Poznaniu i wWarszawie przez zespół socjologów: J oannę Zalewską (Akademia Pedagogiki Specjalnej, kierownik projektu), Martę Skowrońską (Uniwersytet Adama Mickiewicza - UAM) i Filipa Schmidta (UAM) ${ }^{4}$. Były to retrospektywne wywiady pogłębione z diadami (Schmidt et al. 2018),

\footnotetext{
4 W realizacji badań prowadzonych w Warszawie udział brali również Dariusz Jażdżyk i Patrycja Zwolińska. W rekrutacji większości par z Poznania dopomógł Kazimierz Zalewski, za co serdecznie dziękuję.
} 
którymi były małżeństwa, na temat tego, jak wyposażone było ich pierwsze wspólne gospodarstwo domowe i jak kolejne technologie wkraczały w życie codzienne wraz z upływem lat. Wywiady koncentrowały się wokół następujących technologii: media (prąd, woda, gaz), technologie włazience (prysznic, wanna, WC), pralka i telewizor, uwzględniały też inne technologie, wskazane przez respondentów jako istotne. W badaniach wzięły udział 52 osoby. Przeprowadzono 24 retrospektywne wywiady pogłębione z parami małżeńskimi i następujące bezpośrednio po nich wywiady indywidualne z każdym z małżonków z osobna na temat gospodarstwa domowego rodziny pochodzenia (w trzech przypadkach nie było wywiadów indywidualnych, tylko rozmawialiśmy o dzieciństwie również wspólnie w diadzie, ze względu na niechęć par do rozdzielania się). Ponadto, przeprowadzono cztery indywidualne wywiady pogłębione zamiast wywiadu w diadzie, z powodu z trudności w rekrutacji par z najstarszych pokoleń. Wywiady wspomagane były fotografią - zdjęciami różnych modeli wyżej wymienionych technologii. Para badaczy prowadząca wywiad dokonywała ponadto obserwacji na podstawie przygotowanych wcześniej dyspozycji. W kwestionariuszu do wywiadu zawarte były pytania dotyczące emocji w procesie udomawiania technologii: "J akie były Państwa pierwsze wrażenia? J ak się Państwo czuli?”.

Respondenci rekrutowani byli po połowie z Poznania i Warszawy. Podstawowymi kryteriami różnicującymi było pokolenie historyczne oraz kategoria zawodowa. Ze względu na obszerność podjętego zagadnienia, nie poddałam analizie zróżnicowań społecznych, dlatego nie przedstawiam tutaj wyodrębnionych kategorii (por. Zalewska, Skowrońska 2020). Zaznaczę tylko, że rozmówcy byli zróżnicowani pod względem kategorii zawodowych w każdym pokoleniu, w grupie badanej byli robotnicy niewykwalifikowani i wykwalifikowani, pracownicy biurowi i prowadzący własną działalność gospodarczą, specjaliści, a także właściciele i kadra zarządzająca firm / zakładów pracy.

Zgodnie z koncepcją pokoleń historycznych Hanny Świdy-Ziemby (2010), pokolenia łączą podobne doświadczenia społeczno-kulturowe 
i wynikający z nich światopogląd. Oznacza to, że co jakiś czas rysuje się wyraźne pokolenie historyczne obejmujące kilka roczników, są jednak takie roczniki, które nie przynależą jednoznacznie do żadnego pokolenia. Pary były homogeniczne pod względem przynależności do pokolenia. Wyróżniliśmy następujące pokolenia:

P1. Najstarsze pokolenia, osoby urodzone przed 1936 rokiem, a dorastające w okresie okupacji (pokolenie wojenne) i w latach powojennych, gdy państwo socjalistyczne silnieindoktrynowało młodych (pokolenie ZMP) (Szatur-J aworska 2000).

P2. Pokolenie Odwilży (ibidem) / opozycji obyczajowej (ŚwidaZiemba 2010), wchodzące w dorosłość w okresie zmniejszonego terroru po śmierci Stalina, jednakże w latach szkolnych poddane stalinowskiemu systemowi indoktrynacji. Stosowali się do podwójnych reguł: w życiu oficjalnym posłusznie wykonywali wszelkie polecenia, zaś w grupach koleżeńskich cenili wszystko, co nie było komunizmem i co pochodziło z Zachodu (ibidem).

P3. Pokolenie małej reformy i Marca 1968, którego proces dojrzewania przebiegał w okresie tzw. małej stabilizacji, jego przedstawiciele manifestowali brak zainteresowania polityką, skoncentrowani na zdobyciu mieszkania, pracy, rodzinie (ibidem).

P4. Pokolenie podmiotowości i więzi wspólnotowej, wchodzący w dorosłość w latach 70., gdy w PRL-u otworzyły się możliwości konsumpcji, a młodzi buntowali się przeciwko bezosobowemu światu konsumpcji (ibidem).

P5. Pokolenie transformacji ${ }^{5}$, osoby wchodzące w dorosłość w okresie transformacji ustrojowej. Mieli doświadczenie braku stabilności instytucji, pluralizacji wartości i destrukcji wzorów aksjologicznych (Świda-Ziemba 1995).

5 W opisie cytatów oznaczenie „P” z odpowiednim numerem będzie odnosiło się do pokolenia, do którego należy respondent, zgodnie z numeracją powyżej. 
Zebrane materiały kodowane były w programie MaxQDA. Utworzono kod „emocje”, którym kodowano fragmenty, w których osoby badane wspominały o doznawanych emocjach. Te fragmenty przeznaczono do analizy na potrzeby tego tekstu. Na podstawie literatury przedmiotu wyodrębniłam dwa typy emocjonalności dyskurs postępu i nowoczesny hedonizm, odpowiadające J a modernistycznemu i J a romantycznemu. Na bazie analizy materiału scharakteryzowałam funkcjonowanie tych dwu typów emocjonalności w badanej grupie. Aby sprawdzić, czy mamy do czynienia z przemianami, czy ze współwystępowaniem dwu typów emocjonalności, termin przemiany zoperacjonalizowałam jako różnice pomiędzy pokoleniami historycznymi. Zbadałam, czy istnieją różnice między pokoleniami w grupie badanej w występowaniu cech obu typów.

W dalszej części pracy będę używać skrótu myślowego, mówiąc o różnicach pomiędzy pokoleniami historycznymi. Będę miała na myśli odmienności pomiędzy pokoleniami w obrębie grupy badanej, a nie w całej populacji polskiej. Są to badania jakościowe, nie są reprezentatywne dla populacji Polski ani dla populacji Warszawy czy Poznania. Zastosowanie tutaj ma charakterystyczny dla antropologii kulturowej interpretatywny model uogólniania wyników. Mianowicie stosujemy teorie wypracowane we wcześniejszych badaniach, ale pozwalające zrozumieć czy spojrzeć z innej perspektywy na procesy zachodzące wkonkretnej badanej sytuacji, a następnie możemy się zastanawiać, co zdobyta w ten sposób wiedza mówi na temat społeczeństwa, którego dotyczy, a następnie na temat życia społecznego jako takiego (Geertz2003). Teoriajest pośrednikiem pomiędzy jednym terenem badań a drugim. Na podstawie bardzo szczegółowych badań w konkretnym miejscu badacz formułuje, a zwykle rozwija, pewną teorię, którą następnie można zastosować jako model, prowadząc badania w innym miejscu. Prowadziliśmy badania w dwóch miastach, dobierając rozmówców w pełnym przekroju społecznym, osiągnęliśmy nasycenie materiału, dlatego mam nadzieję, że uzyskane wyniki analiz będą mogły stanowić adekwatny model teoretyczny przemian emocjonalności do zastosowania w innych środowiskach miejskich w kontekście polskim. 
Wzrost emocjonalności

W materiałach pojawia się cała gama emocji związanych z procesem udomawiania technologii. Istnieją różnice w liczebności odwołań do emocji pomiędzy pokoleniami historycznymi, czyli w tym, jak często poszczególne pokolenia mówią o emocjach w kontekście udomowienia technologii. Otóż dla pokoleń najstarszych (P1) wśród 824 wszystkich zakodowanych fragmentów, 24 fragmenty zakodowane są kodem „emocje”, co daje 2,91\% wszystkich zakodowanych fragmentów. W przypadku pokolenia Odwilży (P2) jest 26 fragmentów zakodowanych jako „emocje” z 868 wszystkich fragmentów. Daje to 3\%, czyli bardzo podobnie. Dla pokolenia małej reformy (P3) jest 31 fragmentów zakodowanych jako „emocje” z 1055 wszystkich zakodowanych fragmentów. Daje to 2,94\% czyli również bardzo podobnie. Dalej pojawiają się różnice. W przypadku pokolenia podmiotowości i więzi wspólnotowej (P4) mamy 40 fragmentów zakodowanych jako „emocje” wśród 1095 wszystkich zakodowanych fragmentów, co daje 3,65\%. Natomiast w przypadku pokolenia transformacji (P5) mamy 60 fragmentów zakodowanych jako „emocje” z 1321 wszystkich zakodowanych fragmentów, czyli 4,54\%. Zatem widzimy zmianę w kierunku częstszego mówienia o emocjach.

Druga ilościowa zmiana jest taka, że pokolenia młodsze wymieniają więcej emocji niż starsze, mamy więc różnicę w liczbie przywoływanych emocji. Przedstawiciele P1 wymieniają 10 emocji: radość, szczęście, zadowolenie, lubienie; przeżycie, wzruszenie oraz sporadycznie: przyjemność; melancholia; pożądanie, zazdrość. Rozmówcy z P2 wymieniają 13 emocji. Przedstawiciele P3 wymieniają 20 emocji. Respondenci z P4 wymieniają 31 emocje. Przedstawiciele P5 wymieniają 38 emocji. Psychologowie wskazują, żeistnieje szersza gama emocji negatywnych niż pozytywnych, wynika to z przyczyn ewolucyjnych (Turner, Stets 2009), jednakże zupełnie nie przystaje to do emocji wymienianych przez rozmówców. Zdecydowanie dominują emocje pozytywne w stosunku do udomawianych technologii, w dodatku występują właśnie w szerokiej 
gamie wielu odcieni. Tymczasem, emocji negatywnych jest raptem kilka i wmniejszej liczbie odcieni: smutek, niechęć, złość, lęk/ niepokój / wątpliwości - tutaj istnieje więcej niuansów; do emocji negatywnych zaliczyłam również zazdrość a także pożądanie, choć pożądanie ma w sobie pozytywny komponent oczekiwania, marzenia o czymś. Wśród wielości obecnych w materiale emocji wydzieliłam dwie kategorie, wykorzystując tutaj podział emocji pierwotnych dokonany przez Paula Ekmana (za: ibidem). Okazały się przydatne w dalszej analizie. Pierwsza kategoria to emocje wokół szczęścia, czyli afektu pozytywnego, jedynej pierwotnej emocji pozytywnej wyodrębnionej przez Ekmana. Ta kategoria emocji dominuje we wszystkich pokoleniach historycznych, jeśli chodzi o emocje wobec wkraczających technologii. Ztym, że w każdym kolejnym pokoleniu pojawia się więcej określeń emocji z tej kategorii: więcej odcieni szczęścia-radości-zadowolenia i więcej poziomów, świadczących o sile emocji. Druga kategoria to emocje wokół Ekmanowskiej emocji pierwotnej zaskoczenia. W tej kategorii są emocje wskazujące na różny poziom zaskoczenia, a także połączenia zaskoczenia z radością: zachwyt, ekscytacja, fascynacja. Brak tej kategorii w P1. Im młodsze pokolenie, tym używa większej liczby określeń z tej kategorii.

Dwa typy emocjonalności: dyskurs postępu i nowoczesny hedonizm

Porównam charakterystyki tych dwóch typów emocjonalności w tabeli 1, a następnie po kolei omówię je na przykładach. Z góry trzeba uprzedzić, że zastosowanie Campbellowskiego modelu nowoczesnego hedonizmu w stosunku do udomowienia technologii wymaga pewnej korekty. W modelu - jak pamiętamy - konsumpcja danego dobra wiązała się z rozczarowaniem, rzeczywiste posiadania / użycie ustępowało marzeniu na jawie (daydreaming). Natomiast udomowienie technologii, np. wprowadzenie samochodów, telewizorów, oznaczało często gruntowną zmianę życia codziennego i wiązało się z silnymi pozytywnymi emocjami. Co nie przeszkadza, że rzeczywiście wraz z posiadaniem 
jednej technologii, zaczynało się pragnienie i marzenie o kolejnej. Kolejną sprawą, o której trzeba uprzedzić, jest to, że dwa typy emocjonalności to Weberowskie typy idealne. W praktyce mogą się one przenikać, współwystępować w pewnych sytuacjach i wiązać te same przedmioty.

Tabela 1. Dwa modele emocjonalności: dyskurs postępu i nowoczesny hedonizm

\begin{tabular}{|c|c|c|}
\hline & Dyskurs postępu & Nowoczesny hedonizm \\
\hline $\begin{array}{l}\text { Podstawowa motywacja } \\
\text { do konsumpcji }\end{array}$ & Potrzeba & Pragnienie \\
\hline Przedmioty konsumpcji & $\begin{array}{l}\text { Elektryczność, woda bieżąca, ła- } \\
\text { zienka, odkurzacz, pralka Frania, } \\
\text { pralka automatyczna, telefon, } \\
\text { zmywarka }\end{array}$ & $\begin{array}{l}\text { Radio, telewizor, samochód, } \\
\text { pralka automatyczna, magneto- } \\
\text { fon, komputer, Internet, trenażer }\end{array}$ \\
\hline $\begin{array}{l}\text { Uzasadnienie } \\
\text { konsumpcji }\end{array}$ & Racjonalne, funkcjonalne & $\begin{array}{l}\text { Emocjonalne, przyjemnościowe, } \\
\text { dla pobudzenia emocji }\end{array}$ \\
\hline $\begin{array}{l}\text { Zaangażowanie Ja } \\
\text { w konsumpcję }\end{array}$ & Przedmiot nie odnoszony do Ja & Przedmiot jest dla Ja \\
\hline $\begin{array}{l}\text { Poziom społeczny } \\
\text { emocji }\end{array}$ & $\begin{array}{l}\text { Uczestniczę w dzielonych z innymi } \\
\text { emocjach z powodu tego przed- } \\
\text { miotu (kolektywne) }\end{array}$ & $\begin{array}{l}\text { Odczuwam emocje, gdy na dany } \\
\text { przedmiot czekam / marzę o nim, } \\
\text { a potem używam (indywidualne) }\end{array}$ \\
\hline $\begin{array}{l}\text { Emocje poprzedzające } \\
\text { konsumpcję }\end{array}$ & $\begin{array}{l}\text { Coś nowego się pojawia i zadzi- } \\
\text { wia: szok, zdumienie, ekscytacja, } \\
\text { zainteresowanie }\end{array}$ & $\begin{array}{l}\text { Pragnę i marzę, żeby coś mieć / } \\
\text { zdobyć / dostać: pożądanie, } \\
\text { tęsknota, zazdrość, ekscytacja, } \\
\text { fascynacja (dla technologii inte- } \\
\text { raktywnych) }\end{array}$ \\
\hline $\begin{array}{l}\text { Emocje w trakcie kon- } \\
\text { sumpcji, związane z rea- } \\
\text { lizacją podstawowej } \\
\text { motywacji }\end{array}$ & $\begin{array}{l}\text { Ulga, radość, szczęście po zaspo- } \\
\text { kojeniu potrzeby, po dłuższym } \\
\text { czasie zadowolenie }\end{array}$ & $\begin{array}{l}\text { Przyjemność, radość (ze zdoby- } \\
\text { cia, z posiadania), fascynacja (dla } \\
\text { technologii interaktywnych), } \\
\text { duma, po dłuższym czasie zado- } \\
\text { wolenie }\end{array}$ \\
\hline
\end{tabular}

Emocje w trakcie kon-

sumpcji, związane z Wzruszenie, przeżycie, radość w kontakcie z czymś niezwykłym; żyaspektem nowości kate- cie nagle ulega zmianie pod wpływem konsumpcji obiektu gorii przedmiotu 
Podstawowa motywacja do konsumpcji

W zebranym materiale wyraźnie rysuje się kontrast pomiędzy potrzebą a pragnieniem jako motywacją do udomowienia technologii. Pomoc w zaspokajaniu codziennych potrzeb polega na redukcji wysiłku i czasu wkładanych w codzienne praktyki ${ }^{6}$. Ta rola udomowienia technologii była bardzo ważna dla starszych pokoleń (P1, P2), stopniowo dla młodszych stawała się przezroczysta.

K: Frania miała wyżymaczkę, to pót roboty. M: To było wydarzenie te pralki. To było wydarzenie. O Jezu. K: Przeżyłam, ale muszę Pani powiedzieć, że teraz to mam jak w niebie. (Waw12P1)

W powyższym cytacie widzimy, że pralka Frania redukowała zdaniem rozmówczyni wysiłek o połowę. Emocjonalna wypowiedź mężczyzny wskazuje, jak ogromne znaczenie miało ówcześnie udomowienie technologii w zakresie uproszczenia organizacji konsumpcji (Czerwiński 1969). Druga wypowiedź kobiety - „przeżyłam” wskazuje na bardzo wysoki poziom deprywacji potrzeb przed udomowieniem technologii, a także na stale odczuwane emocje pozytywne o wysokim natężeniu związane z emocją pierwotną radości z powodu stałego i regularnego zaspokajania potrzeb.

Wymienione poniżej motywacje zaklasyfikowałam jako pragnienie. Uprzyjemnienie życia, ponieważ pogoń za przyjemnością jest elementem definicyjnym pragnienia. Realizację zainteresowań, ponieważ zainteresowania stają się motorem działań już po zaspokojeniu potrzeb. Realizację wizerunku osoby nowoczesnej, co oznaczało zastosowanie idei postępu we własnym życiu: posiadanie nowoczesnych technologii w nowocześnie urządzonym mieszkaniu zakładało wyobrażanie sobie

\footnotetext{
${ }^{6}$ Praktyki społeczne rozumiem jako wcielone, zapośredniczone przez przedmioty wiązki ludzkiej aktywności zorganizowane wokół podzielanego praktycznego rozumienia (Schatzki 2001).
} 
przyszłej nowej sytuacji i wzbudzało emocje - cechy charakterystyczne dla nowoczesnego hedonizmu.

Funkcję uprzyjemnienia życia dla pokoleń najstarszych (P1) miało udomowienie telewizora. Można zakup telewizora postrzegać w kategoriach tradycyjnego hedonizmu. Nie ma tu mowy jeszcze o tym marzeniu i wyobrażaniu sobie posiadania czy użycia przedmiotu, nie angażuje obrazu Ja, raczej oglądanie telewizji jest takim osobnym wydarzeniem, osobną „przyjemnością”, doznaniem zmysłowym, któremu można się oddać.

Mój syn miat, ten młodszy, chyba ze dwanaście lat, jak kupiliśmy, to już tak siadt, to musiat okulary założyć. Jak usiadt przy tym telewizorze, to już nie można go było oderwać. (...) I on tak się cieszyt. A dlaczego się państwo zdecydowali na kupno telewizora? Bo chyba to jest taka odskocznia, przyjemność. Jak przyjdę, to też sobie oglądam te seriale wieczorem. (Waw10P1)

Podobnie odbierana jest jazda na motorze jako zmysłowa przyjemność, tym razem w $\mathrm{P} 2$ :

Mą̇̇ kupit Pannonię. Kupit Pannonię, to było coś dla mnie, ja bardzo lubiłam na motorze jeździć, jeździć z mężem, bo to jest taki pęd powietrza, w samochodzie to czlowiek usiądzie i siedzi tu obudowany i kieruje, a ten pęd powietrza na motorze to jest coś takiego, co nie wiem, ale to, to inaczej się odbiera, naprawdę. (Poz15P2)

Tymczasem realizacja zainteresowań nosi cechy nowoczesnego hedonizmu. Pierwszy przypadek zainteresowań realizowanych przy pomocy technologii pojawia się w wypowiedzi przedstawiciela pokolenia Odwilży (P2), u rozmówcy, którego żona jest cytowana powyżej. Mówi on o zakupie radia na baterie w prezencie dla ojca, który interesował się wydarzeniami na świecie. Radio ma więc służyć do zaspokajania aspiracji intelektualnych, pozwalać mu na bycie „światowym człowiekiem”. 
Przy czym światowy człowiek jest pewnym wyobrażeniem na własny temat, które wzbudza emocje, dlatego uważam ten przypadek za przejaw nowoczesnego już hedonizmu.

I ponieważ ojciec, ojciec byt taki facet, co $w$ pierwszej wojnie światowej, potem byt $w$ czasie drugiej $w$ Hamburgu wywieziony i ponieważ rozmawiat po niemiecku, więc tam jakieś miał nawet stanowisko i z Niemczech przyjechat, to już byl facet taki troszeczkę bardziej, że tak powiem, światowy i bardzo mu zależało, żeby co, a już tam styszat $w$ Niemczech, już te radia mieli, nie, jeszcze za okupacji, więc on mówi, cholera, jak to zrobić, żeby radio, ale mówi, no prądu nie ma, no co to tu, jak tu, bo bez, nie bylo tak w ogóle, no i wtaśnie będąc gdzieś $w$ terenie patrzę, radia sq takie Pioniery, takie plastikowe opakowanie, i ja mówię, kupię ojcu to radio. No i zrobitem mu taki prezent, zawioztem mu z bateria, podtaczytem, mówię, zobacz, postuchaj sobie. Ucieszyt się. Ucieszyt się jak cholera. (Poz15P2)

Realizacja upragnionej wizji życia oznaczała zazwyczaj osiągnięcie odpowiedniej pozycji społecznej dzięki posiadaniu na wyposażeniu mieszkania dóbr materialnych i technologii na poziomie przynajmniej takim jak w większości ówczesnych mieszkań. Obecna była we wszystkich pokoleniach z wyjątkiem pokolenia transformacji (P5).

W zakresie udomowienia technologii polegała zazwyczaj na stopniowym kupowaniu kolejnych przedmiotów. Wyrastała z dyskursu postępu, pierwsze kupowane technologie służyły redukcji wysiłku i ułatwieniu w organizacji konsumpcji. Ta wizja życia była również związana z koncepcją człowieka nowoczesnego, który podąża za nowościami i adaptuje kolejne technologie. Wynikała z dyskursu postępu, ajednak podlegała prawom nowoczesnego hedonizmu, polegała na wyobrażeniu sobie siebie jako osoby nowoczesnej, czemu odpowiadało odczuwanie emocji. 
No to $w$ sześćdziesiątym siódmym się sprowadziłam tu, no to był sześćdziesiąty ósmy załóżmy. Kupiłam ten telewizor. Już dzieci nie miały... Moje dzieci musiały być w domu. To nie było tego, że ulica chodziła. Nie. Ulica nie wychowa dzieci. (...) Lodówkę to już miałam tutaj na Gajcego, bo potem tak sukcesywnie, bo najpierw trzeba było spanie, potem dzieciom trzeba było jakiś kąt, bo tu na Gajcego miałam dwa pokoje i kuchnia... (Waw12P1)

\section{Przedmioty konsumpcji}

Przedmioty konsumpcji zostały podzielone na zaspokajające potrzeby i przedmioty pragnień. Osoby, które pamiętały jeszcze elektryfikację, przedstawiały udomowienie elektryczności jako pierwszy i najważniejszy etap w procesie ułatwienia organizacji konsumpcji, czyli zaspokajania potrzeb.

No ale takie mówię, z dzieciństwa to największa rewolucja to jest... Prąd. Elektryczność. I potem związane z tym światto, silniki elektryczne. No jasne. To było. Ale to były lata czterdzieści osiem, pięćdziesiąt. Tak, tak. I mi się to podobato. (Poz14P2)

Elektryfikacja wsi zakończyła się w połowie lat 70. XX wieku (Komorowski, 2018), tak więc przebieg czasowy był zróżnicowany i w związku z tym część przedstawicieli pokoleń historycznych P1, P2 i P3 doświadczyło tej zmiany w swojej codzienności.

Wśród technologii zaspokajających potrzeby należy też wymienić bieżącą wodę i łazienkę wraz ze wszystkimi utensyliami; pralkę Franię i pralkę automatyczną tzw. automat - tę jednakże traktowano na początku jako luksus i przedmiot pragnień ze względu na to, że redukowała wysiłek niemalże do zera. Telefon i zmywarka były wymieniane jako usprawnienie.

J eśli chodzi o technologie zaspokajające pragnienia, to chodziło tutaj o wszystkie przedmioty, których używanie mogło sprawiać przyjemność, 
ale także o te, które pozwalały zrealizować upragnioną wizję życia i posiadać mieszkanie wyposażone w zgodzie z aspiracjami człowieka nowoczesnego, więc dlatego realizację pragnień umożliwiały tė̇ te technologie, które pozwalały zaspokajać codzienne potrzeby, jak pralka automatyczna nazywana automatem czy zmywarka.

\section{Uzasadnienie konsumpcji}

Można rozróżnić z jednej strony racjonalne uzasadnienie udomowienia technologii, w ramach którego wskazywane są konkretne zadania udomawianych technologii i praktyczne korzyści wynikające z ich udomowienia; zaś z drugiej strony uzasadnienia związane z pobudzaniem emocji, np. dla frajdy lub unikanie nudy. Przykładem konkretnego zadania może być szybkie posprzątanie, dające korzyść niekolidowania z zaangażowaniem w pracę zawodową:

No następną rzeczq, którq̨ kupiliśmy, jak już dostaliśmy mieszkanie, to byt elektrolux (odkurzacz). Acha. To była radość, bo można byto szybko zrobić porzadek $w$ mieszkaniu, szczególnie jak się pracowato, ja na dyżurach, wracatam po dyżurach, nie było wolnego dnia, to się normalnie ciagnęlo następny dzień pracy w klinice. (Poz12P2)

Teraz skoncentrujmy się na emocjonalnym uzasadnieniu udomowienia technologii - dla pobudzenia emocji. Element motywacyjny (poszukiwanie przyjemności) i emocjonalny w modelu nowoczesnego hedonizmu się splatają - przyjemność daje pobudzenie emocji. Można udomowić technologię, ażeby uniknąć nudy, czyli wzbudzić emocje pozytywne w miejsce znużenia. W zebranym materiale jest bardzo ciekawy przypadek użytkowania trenażera kolarstwa szosowego, w którym do roweru treningowego podłączony jest monitor i aplikacja typu multiplayer, czyli można daną trasę przejechać koło w koło z innymi graczami, ścigać się, porównywać wyniki. Urozmaica to zimowe treningi: 
Tojest właśnie ten plus, że zabiło nudę. Kiedyś też tam mieli rolkowe ileś lat temu, to jeździli na takich rolkowych trenażerach, ale to nuda jak nie wiem. (Waw1P5)

Uzasadnienie emocjonalne „dla frajdy” właściwie pokrywa się z motywacją dla przyjemności, tak więc tutaj również można by opisać omówione z podrozdziale pierwszym udomowienie telewizora dla przyjemności. Bardzo podobne emocjonalne uzasadnienie miało udomowienie magnetofonu, komputera, Internetu. Jeśli zaś chodzi o udomowienie samochodu, to dawał on poczucie wolności, swobody i radość / przyjemność z wyjazdów na wakacje.

Motoryzacja, to ja poczulem się taki wolny... Acha. Mówię pani, byłem szczęśliwy, że jestem wybrańcem, no [niezrozumiałe] samochodu tam jak $w$ Cegielskim, to ho ho, o, samochód, o samochód, o samochód, skąd ja mam samochód... (Poz5P3)

J edna z rozmówczyń z pokolenia transformacji używa wręcz określeń „Wzruszać, poruszać emocje”, mówiąc o telewizorze. Tak więc pobudzanie emocji było podstawową funkcją, z której użytkownicy zdawali sobie sprawę, przynajmniej w przypadku niektórych udomowionych technologii.

Programy dla dzieci na przykład, to one miahy mieć określone walory poznawcze, edukacyjne. One miały wzruszać, poruszać emocje. (Waw1P5)

Rozmówcy zdają sobie również sprawę z różnicy pomiędzy technologiami spełniającymi potrzebę, kupowanymi racjonalnie dla ich funkcji, oraz przedmiotami pragnień wzbudzającymi emocje:

M: Funkcje, znaczy AGD u nas zawsze bylo sprowadzone do swojej funkcji, tylko i wyłacznie, to nie budziło [emocji], samochód na początku budzit... B: 
Samochód. M: ...emocje. B: Ok. M: Bo to byt pierwszy samochód. B2: Garbusik. B1: Tak. M: Bo był garbaty, bo... (Poz10P5)

W kontraście do powyższej wypowiedzi warto pokazać, że przedstawicielka P1 zwraca uwagę na to, że wśród młodszych pokoleń technologie zaspokajające potrzeby traktowane są bez emocji, funkcjonalnie, albo wręcz jako przezroczyste. Natomiast, gdy wkraczały do gospodarstw domowych, dawały jednocześnie poczucie przyjemności. J est to zgodne z tym, co pisał Campbell, że w sytuacji, gdy potrzeby nie są zaspokajane regularnie i stale, ich zaspokojenie wiąże się z przyjemnością.

No to kapaliśmy się, ja tam prałam, pralka stała, już miałam pralkę normalna, phukatam $w$ tej wannie, wykręcilam, było lepiej. Cieszyłam się z wody, że mam tę tazienkę $i$ tę wodę. Teraz ludzie tego nie doceniaja wcale, bo mają to od początku, to uważają, że tak musi być (Waw10P1)

Zaangażowanie Ja w konsumpcje

Technologie zaspokajające potrzeby różnią się od technologii będących przedmiotem pragnienia sposobem zaangażowania w użytkowanie ich. Technologie zaspokajające potrzeby nie są wykorzystywane do tworzenia tożsamości, nie są odnoszone do Ja, nie zmieniają obrazu J a. Tymczasem użytkowanie przedmiotów pragnień polega na zaangażowaniu J a w obiekt i staje się elementem budowania czy określania tożsamości.

Zacznijmy od technologii nie odnoszonych do Ja. Technologia jest czymś zewnętrznym wobec Ja, nie widać tutaj zaangażowania technologii w kwestie określające tożsamości aktorów. Można podać przykład bardzo pozytywnego stosunku, świadomości zmiany życia, a jednak przedmiot pozostawał czymś zewnętrznym, nie brał udziału w określaniu tożsamości: 
Na tych pipidówkach to zaczęli zakładać światło w 47., 48. roku. Przecież jak mnie facet opowiadal, który te rzeczy robit - proszę pana, jak myśmy zapalili to elektryczne światto ludziom, wie pan, jak ludzie płakali, że doczekali tych lat. Żeby zobaczyć, że światto się pali. Przecież ludzie nie znali. (Waw12P1)

Przejdźmy do użytkowania przedmiotów pragnień. Wśród wypowiedzi na temat emocji w pokoleniu transformacji (P5) zdecydowaną większość stanowiły wypowiedzi zaklasyfikowane do tego typu. Emocje pojawiające się w sytuacjach, gdy technologie nie uczestniczyły w określaniu tożsamości, były bardzo nieliczne. Tłumaczyć to może wypowiedź starszej rozmówczyni (P1) przytoczona we wcześniejszym podrozdziale, gdziejest mowa o tym, że młodsze pokolenia nie doceniają funkcjonalnych technologii, są im obojętne. Liczba emocjonalnych wypowiedzi jest w P5 największa i składa się głównie z emocji doświadczanych w kontakcie z technologiami angażującymi J a. Tymczasem w starszych pokoleniach emocjonalnych wypowiedzi jest mniej, a do tego część z nich dotyczy technologii zaspokajających potrzeby. Wygląda więc na to, że pokoleniu transformacji jest już znacznie lepiej ukształtowane charakterystyczne dla nowoczesnego hedonizmu połączenie między domową technologią, przyjemnością, emocjami i tożsamością.

Użytkowanie przedmiotów pragnień wzbudza emocje i przynosi przyjemność - to już wiemy. To, żejednostka użytkuje takie a nie inne przedmioty pragnień, wchodząc w takiea nieinne praktyki, jest elementem jej tożsamości, w pewien sposób ją określa, każda jednostka angażuje się tylko w niektóre przedmioty pragnień. Wielu przedstawicieli P5 miało swoje pasje, zainteresowania, fascynacje, które realizowało za pomocą udomowionych technologii i wtedy same te technologie darzone były sentymentem. Wśród tych pasji, w które rozmówcy się angażowali były: trenowanie kolarstwa szosowego na trenażerze, muzyka, komputery i technika procesorowa, zaangażowanie w społeczność miłośników rzadkich perfum, piękno własnego ciała, wyprawy i „włóczykijowanie”, wspólnota religijna, życiejak najbardziej zgodne z naturą. Dla 
realizacji większości z tych pasji domowe technologie miały kluczowe znaczenie, a dla innych poboczne.

Obrazowo zaangażowanie J a w poszukiwanie przyjemności można pokazać na przykładzie wypraw i „włóczykijowania”. Małżeństwo z pokolenia transformacji uwielbia jeździć samochodem na wycieczki, przy okazji właściwie pobocznych celów lubi przemierzać wiele kilometrów samochodem. Ta przyjemność jest wpisana w ich subiektywną tożsamość, w to, kim się postrzegają. Tak więc w ich przypadku samochód pozwala im na spełnianie pragnień, ponieważ są „włóczykijami”. Ich subiektywna tożsamość podkreślona jest wzmianką, że nikt zich otoczenia tych przyjemności nie potrafi zrozumieć. To miałam na myśli, zaznaczając w tabeli, że technologie są „odnoszone do J a”. Dają ludziom przyjemność ze względu na specyficzne cechy osobowościowe tych osób, ich tożsamość. Banalnie można to podsumować w ten sposób, że podstawowe potrzeby są takie same dla wszystkich, a przyjemności są zróżnicowane.

K: No tak. My jesteśmy włóczykije straszne. Ciagle się włóczymy. (...) A nie no, my przecież potrafimy pojechać na pizzę do Łodzi, bo przecież $w$ Warszawie nie można zjeść pizzy. (...) Do Radzymina do cukierni na lody. Najpierw do Radzymina a później pod Ostrów. (...) M: 70 km, nie mniej. K: Ale nam się zdarza rzeczywiście. Dla nas to nie jest jakiś problem. Ale dla jasności do tej Łodzi to my pojechaliśmy do Pizza Hut. To nie, ze w Łodzi jest jakaś pizza, pizzeria specjalna. M: Jechaliśmy, żeby się przejść, bo tam lubimy się przejść. K: Nikt tego nie jest $w$ stanie zrozumieć. (...)M: Dla nas wycieczka się zaczyna $w$ momencie, kiedy wsiadamy do samochodu. (Waw4P5)

Innym przykładem jest trenowanie kolarstwa szosowego na trenażerze. Wymagało skomplikowanego sprzętu: ekranu / komputera, Internetu, telefonu komórkowego i aplikacji internetowej w telefonie, wreszcie trenażera - roweru stacjonarnego i sporej wiedzy o nowinkach w tym zakresie. Zaangażowane rozprawianie rozmówcy na temat trenażera 
i trenowania, zajmuje cztery strony transkrypcji, ale jest to liczone jako jeden zakodowany fragment kodem „emocje”. Dodatkowo, trenowanie dawało przynależność do społeczności używających trenażery w aplikacji komórkowej.

Jest oczywiście czujnik tętna. No to $w$ górach konieczne, żeby nie przesadzić. Czujnik kadencji, czyli ile się kręci pedałami na minutę. A oprócz tego teraz w sezonie zimowym większość jeździ już na trenażerach. Tojest niesamowite. To jest cztery lata temu zaczątem jeździć na takich, jest taka aplikacja internetowa, gdzie się podtącza trenażer. Ten trenażer ma czujnik mocy, to jest przekazywane przez antenę do komputera, do tej aplikacji i normalnie jest... wirtualne trasy są. Awatary. Czyli ja tam siebie widzę. Ale też widzę ludzi z całego świata, którzy akurat jadą w tym samym czasie. (Waw1P5)

Rozmówca wprost nie podnosił kwestii tożsamościowych. J ednak poświęcał tej czynności wiele czasu i wysiłku, co świadczy o zaangażowaniu oraz trenujących towarzyszy określał mianem „wszyscy”, co można rozumieć jako przynależność i silne utożsamienie ze społecznością. Ten rodzaj zaangażowania różni się od opisanego wyżej „włóczykijowania” pewną interaktywnością samego obiektu zaangażowania. Warto tu przywołać teorię Karin Knorr-Cetiny (1997), która stworzyła koncepcję zaangażowania w obiekt, tworzenia relacji z obiektem. Obiekt nie jest obiektywnie sprawczy, ale jednostka w ten sposób subiektywnie go odbiera. Obiekt ma jakiś brak, jednostka stara się ten brak uzupełnić, co się udaje, ale następnie widzi kolejny brak i w ten sposób: akcja-reakcja relacja ta trwa. Relacja opiera się na mechanizmie projekcji-identyfikacji. Na obiekt człowiek projektuje własne uczucia, a następnie z nim się utożsamia - wczuwa się w niego. Obiektem w analizach Knorr-Cetiny były pantofelki, czyli istoty żywe - obiekty badań naukowych, jednak autorka wskazywała, że może być to dowolny inny projekt, który angażuje J a do działania, niejako wciąga w swój świat i „domaga się” dalszych interakcji. Niejestem pewna, czy w przypadku innych projektów 
- inżynieryjnych, pisania artykułu dziennikarskiego czy trenowania mechanizm projekcji-identyfikacji równiė̇ działa. Na pewnojednak działa w opisanym przypadku struktura braku, ciągła konieczność dopracowania obiektu, która angażuje emocje i namysł. W przypadku trenowania na trenażerze mamy po pierwsze ciągłą poprawę sprzętu, aby uzyskać prawdziwszy, wzbudzający więcej emocji efekt, zaś z drugiej strony dążenie do doskonalenia sportowego i poprawy tzw. „osiągów”.

Kolejny przykład to zaangażowanie w obiekt, gdy obiektem tym jest stricte technologia i sama interakcja z nią daje przyjemność. Rozmówca informatyk, również na czterech stronach transkrypcji, opowiadał o swojej fascynacji techniką, która doprowadziła go do wyboru roli zawodowej - jednego z najważniejszych elementów tożsamości.

W sumie to się idzie za głosem serca. Bardziej za tym, co ciagnie. Mnie to zawsze informatyka ciagnęła, aczkolwiek też przechodziłem kolejne etapy, od fascynacji programowaniem, gdzie programowatem wszystko, (...) a potem powolutku mi przechodziło $w$ administrację, $w$ poznawanie nowych systemów uniksowych... (Waw4P5)

Wyraźnie rozmówca mówi o tym wciąganiu, „domaganiu się” działań ze strony obiektu, a własna aktywność jest postrzegana jako podążanie za tym zewem. Zaangażowanie w obiekt pojawia się po raz pierwszy w P3, ale tylko w przypadku jednego rozmówcy, tam chodzi o zaangażowanie w radio i tworzenie studenckich audycji radiowych.

\section{Poziom społeczny emocji}

Tu rozróżnienie dotyczy tego, czy emocje są współdzielone w ramach jakiejś społeczności czy też są odczuwane indywidualnie. Zdaniem Sary Ahmed (2014), emocje służą do wyodrębniania obiektów z przestrzeni społecznej, zarówno obiektów czujących, jak i tych wobec których emocje są kierowane, oraz ustalania ich relacji. W związku z tym 
uczestniczenie wemocjach współdzielonych z innymi ustanawia pewien kolektywny byt, zaś odczuwanie emocji indywidualne wyodrębnia jednostkę ze zbiorowości. Gdy spojrzymy na obydwa przykłady (pralka automat i elektryfikacja) nieodnoszonych do J a technologii w poprzednim podrozdziale zobaczymy tam pewną grupę zjednoczoną wspólnym odczuwaniem, w jednym przypadku byli to członkowie dalszej rodziny, w drugim cała wieś. W materiale jest bardzo dużo przykładów wspólnego odczuwania w obrębie rodzin:

M2: Jak się coś kupito, to była wesotość $w$ domu, nie. Coś się kupi, jak to tam ten telewizor, radio, nie, radio. (...) Ale moim zdaniem byto weselej, bo byt większy kontakt z ludźmi. Mhm. A dzisiaj każdy ma komórkę, drugiego nie widzi. (...) M2: Oj, to była uroczystość. K: Była, była uroczystość. M2: Na dach wchodzitem do góry... K: no żeby założyć antenę. (...) M2: Trzech musiało być. K: No żeby ustawić. M2: Jeden na dole, jeden $w$ mieszkaniu... (Poz3 P3K4)

Z kolei emocje odczuwane indywidualnie zdarzały się w przypadku większości wspominanych w poprzednim podrozdziale pasji. Zjednym wyjątkiem - pary „włóczykijów”, gdziejak sądzę wspólne wyprawy były elementem ich łączącym, stanowiącym między innymi praktykami o tożsamości pary. Ponadto, o ile emocje wyodrębniały jednostki oddane swojej pasji z otoczenia społecznego, to jednocześnie dawały szansę na połączenie $z$ innymi jednostkami, poza najbliższym otoczeniem fizycznym, we wspólnoty jednostek zaangażowanych w dany obiekt oraz podzielania emocji w tych powstałych wokół obiektu grupach, tzw. wspólnotach projektowych (Olcoń-Kubicka, 2009).

Igorowi [mężowi] to w ogóle obojętne, bo jeszcze mu wtedy Internet nie byt potrzebny i nawet go nie chciat poznawać, a ja siedziałam sobie do nocy na forach i potrafiłam na forach, gdzie się zaprzyjaźnitam z ludźmi, z którymi się zaprzyjaźniłam $w$ realu, potrafilam do trzeciej $w$ nocy siedzieć i pisać. A jakie to byhy tematy tych forów? Raczej to byto takie specjalistyczne forum o perfumach, 
gdzie była taka grupa maniaków, mitośników niszowych perfum, których jeszcze wtedy $w$ Polsce nie byto. (Waw3P5)

\section{Emocje poprzedzajqce konsumpcje}

W ramach dyskursu postępu propagowany był zachwyt nad postępem, nowoczesnością, w tym nowościami technologicznymi. Z kolei w modelu nowoczesnego hedonizmu kluczowe są emocje odczuwane jeszcze przed przystąpieniem do konsumpcji: wyobrażanie sobie, marzenie, pożądanie. W typie emocjonalności dyskursu postępu pierwszy kontakt z nową technologią ujęłam określeniem: „coś nowego się pojawia i zadziwia" - wywoływało zainteresowanie, zadziwienie, zdumienie, ekscytację, zachwyt, szok - czyli te emocje z grupy emocji pierwotnej zaskoczenia.

Ponieważ miałem znajomych $w$ Krakowie, to najpierw $w$ Krakowie poprositem, żeby mnie... Acha, wcześniej bylem na dworcu kolejowym i zobaczyłem, że toaleta jest $w$ postaci dziury $w$ ziemi i trzeba przysiąść, zrobić potrzebę swoja i tam wodę się opuszczało, ale było śmierdzaco, brudno. A później, jak bylem w Krakowie u znajomych to zobaczylem, że może być jak pokój mój. Wy tu macie nie toaletę - mówię - tylko pokój macie. No i wtedy można było naciskając na przycisk opróżnić zawartość. Można się było umyć, ręce, obok byt kran z woda. Było zaskoczeniem dla mnie petnym. Proponowatem $w$ domu, ale ojciec mówi - no niestety, u nas takiej możliwości nie ma. Nie ma wody bieżącej. (Waw8P3)

W kategoriach dyskursu postępu postrzegane były wszelkie nowinki technologiczne, zarówno technologie, które następnie zaspokajały potrzeby, jak i te które potem przynosiły przyjemność. Poniżej daję przykład pierwszego kontaktu z telewizją, ale podobną historię opowiedziała również przedstawicielka P4, gdy za granicą miała styczność z telewizją satelitarną. 
Pamiętam, gdzie ja byłam, w Domu Stowa Polskiego chyba, i tam był pokazywany telewizor i wtedy tam zobaczyło się telewizor, biało-czarny oczywiście, no sensacja niesamowita [śmiech], coś fantastycznego, no a później powoli, powoli, prawda. (...) No a myśmy zreszta obserwowali, co się dzieje w Warszawie... (Waw2P2)

Ani spotkanie z telewizorem ani z telewizją satelitarną nie było wcale początkiem pragnień posiadania wynalazku czy marzeń o nim. Były potraktowane z zachwytem jako wytwór postępu.

Nowoczesny hedonizm wiąże się z kolei z uporczywym marzeniem czy pożądaniem danego przedmiotu, emocje wyrażane w tych sytuacjach to: pożądanie, tęsknota, zazdrość, ekscytacja, fascynacja (dla technologii interaktywnych). W wypowiedziach rozmówców z najstarszych pokoleń (P1) są tylko dwa fragmenty zawierające te emocje. Jeden dotyczy już lat 90. XX wieku i pragnienia posiadania wreszcie telewizora kolorowego, zaś drugi zawiera informacje o zazdrości kolegów z pracy, gdy jedno z małżeństw dostało mieszkanie. O własnych marzeniach konsumpcyjnych (oprócz tego telewizora kolorowego w okresie już po transformacji ustrojowej) przedstawiciele P1 nie wspominają. Bardzo podobnie w pokoleniu Odwilży (P2): wjednym z wywiadów przewija się temat zazdrości sąsiadów o samochód, który rozmówcy mieli jako pierwsi w okolicy oraz stwierdzenie, że „każdy chciał mieć” pojawia się jako powód zakupu kolorowego telewizora. W pokoleniu małej reformy (P3) mamy równiė tylko dwa wątki w dwóch fragmentach, które można zaklasyfikować jako chęć posiadania danej technologii. J eden to przypadek toalety cytowany powyżej, proszę jednak spojrzeć, że nie ma tam expressis verbis wyrażonego marzenia posiadania, wyobrażania sobie i wyczekiwania, tak charakterystycznych dla nowoczesnego hedonizmu, jest tylko krótka propozycja - załóżmy i odpowiedź ojca - nie ma warunków. Druga wypowiedź dotyczy długiego oczekiwania na telefon, ale wypowiedź ta nie wyraża pożądania, to oczekiwanie nie jest zbyt emocjonalne i nie wikła wyobraźni. Raczej oczekiwanie należałoby 
zaliczyć do emocji wpisanych w dyskurs postępu, pojawia się też w kontekście technologii wymienianej jako usprawnienie.

Emocje poprzedzające konsumpcję charakterystyczne dla nowoczesnego hedonizmu pojawiają się wyraźnie dopiero w P4. Mamy tutaj trzy fragmenty, dwa zawierają zazdrość, a jeden właśnie silne pożądanie. Młoda dziewczyna zazdrościła znajomym mieszkania w kamienicy. Innej młodej dziewczynie zazdroszczono magnetofonu. I - co najbardziej wyraziste - młody chłopak bardzo pragnął i marzył o magnetofonie:

Nie miatem, dhugi czas nie miatem magnetofonu, tak żeby sobie nagrywać z radia czy coś, za czym zawsze tęsknilem, bo...Żeby nagrać. No, żeby nagrać sobie coś... (...) No tak, że to byloby piękne, wtedy mogę taka ptytę, którq mam od lat i ja kocham, przegrać wtaśnie $w$ ten sposób, przenieść do samochodu, włączyć sobie. (Poz8P4)

Różnica pomiędzy tym cytatem a zamieszczonymi wcześniej w tym podrozdziale tkwi w otwartym wyrażeniu pożądania / tęsknoty i w intensywności sposobu wyrażania emocji. Oczywiście nie możemy wnioskować o sile odczuwanych emocji, jedynie o sile wyrażanych na zewnątrz emocji. Tym niemniej, jak dowodzi Campbell, nowoczesny hedonizm jest charakterystyczny dla podmiotu romantycznego, który wyraża emocje w sposób intensywny. Można tutaj próbować się zastanawiać, czy we wcześniejszych pokoleniach te emocja pożądania była poddawana supresji, aby nie prowadziła do niepożądanych społecznie zachowań, raczej niż „obrabiana” w ten sposób, by ją otwarcie wyrażać, alejednak kontrolować. Ciekawe, żerozmówcy wcześniej postrzegali zazdrość, czyli to pożądanie u innych, z zewnątrz. Były to sytuacje, gdy prowadziło ono właśnie do niepożądanych społecznie zachowań: koledzy z pracy napisali donos na rozmówce, by ten nie dostał mieszkania; sąsiedzi robili afronty, „awantury”, wypytywali, skąd rozmówcy mieli środki na samochód. Przyznanie się wprost do odczuwania zazdrości pojawiło się dopiero w wypowiedziach $\mathrm{P} 4$. 
W pokoleniu transformacji (P5) jest trzynaście fragmentów, w których są wyrażone wskazane emocje poprzedzające konsumpcję technologii i do tego jeszcze cztery fragmenty, w których pojawiają się te emocje wobec innych dóbr lub praktyk. Znów pojawiło się pragnienie posiadania sprzętu muzycznego, ponadto odpowiedniego wyposażenia łazienki oraz Internetu. Rozmówca informatyk nie poprzestawał na zachwycie technologiami, tylko pragnął je mieć:

Ja byłem zawsze zafascynowany techniką. Zawsze chciatem miećjakieś nowinki, jakieś... Chciatem? Nie było mnie stać w sumie, ale byłem zawsze zafascynowany nowinkami różnymi technologicznymi. Strasznie technologię lubilem. Do tej pory lubię zresztq technologię. Komputer to ja miatem jakiś pierwszy, magnetowid to ja też kupitem do domu rodzinnego, znaczy... tak magnetowid, to byt magnetowid. Jak bylem maly to sobie uzbieratem na magnetofon, pamiętam jeszcze jak na [dzielnica Warszawy] mieszkaliśmy. Ja sobie kupowatem jakiś kalkulator. Też pierwszy, to mama mi pomagata, żebym sobie uzbierat pieniądze. Jakiś kalkulator BRDA12, na osiem paluszków (...). Do tej pory go zresztq mam. (Waw5P5)

Obok pożądania pojawia się również zazdrość, identycznie jak w P4 młodej dziewczynie inni zazdroszczą magnetofonu, zaś inna młoda dziewczyna zazdrości kolegom mieszkania tym razem w bloku. W wypowiedziach P5 pojawia się nagłe pożądanie i natychmiastowa, impulsowa jest realizacja.

Podsumowując, pożądanie, aby udomowić technologię zostało otwarcie wyrażone przez przedstawiciela pokolenia podmiotowości i więzi (P4), natomiast w pokoleniu transformacji (P5) jest powszechnie wyrażane przez rozmówców. Wcześniejsze pokolenia nie wyrażają pożądania wobec posiadania technologii. Weźmy pod uwagę, że Colin Campbell zauważył zbieżność pomiędzy rewolucją konsumpcyjną a początkiem wprowadzania w życie idei, że miłość romantyczna jest właściwym powodem małżeństwa. Można sądzić, że nowoczesny hedonizm ustanawia 
nierozerwalne połączenie pomiędzy pożądaniem a posiadaniem, zagarnięciem dla J a, nie tylko technologii czy przedmiotów, ale w każdej sferze życia. Pożądanie jest otwarcie wyrażane i ogniskuje uwage podmiotu. Napięcie, jak twierdzi Campbell, leży w czasie poprzedzającym konsumpcję - w pragnieniu, marzeniu, domagającym się posiadania.

Emocje w trakcie konsumpcji, zwiqzane z realizacja podstawowej motywacji

Udomowienie technologii pomagających w zaspokajaniu potrzeb przynosi ulgę. Emocja ta jest wyrażana przez starsze pokolenia: P1, P2 i P3.

W naszym starym domu nie założyli gazu. Jak żeśmy dostali [nowe mieszkanie] to byt. Była kuchnia normalna na cztery fajerki. Była to ulga. Nie trzeba już było... zapałkq się podpalito i... Jak ja wrócitam z pracy o dwunastej $w$ nocy, to ja bym gotowała? Kiedy? Ale spałam na siedzaco. Taka byłam zmordowana, że Boże. Ja nie miałam czasu się wyspać. Nie miałam. Kto wstawat rano, to już wiedziałam $w$ tych domach, bo siadałam na oknie, dzieci spaty, a ja brałam wykończenie później, żeby zarobić. (Waw10P1)

Emocje, która się pojawiaj a w pierwszym okresie udomowienia, to radość i szczęście. Wiążą się one z tym, że gdy następuje zaspokojenie potrzeby po okresie deprywacji, to wiąże się ono z przeżyciem przyjemności. Radość i szczęście to emocje podstawowe wskazujące na dobrostan, sytość, pelne zaspokojenie potrzeb po czasie deprywacji i trudu.

Jak ja dostałam to mieszkanie i przychodziłam z pracy, bo później pracowałam nie chatupniczo tylko tam $w$ kiosku, w instytucie, to wszystko ściagałam i prałam - tak się cieszyłam, że ja tę wodę mam i tę pralkę. Oj, jak ja się cieszyłam! Co dzień prałam, jak tylko przychodziłam. Nie mogłam się nacieszyć, że ja wodę mam. Naprawdę? Tak. Uciecha była. (Waw10P1) 
W późniejszym okresie użytkowania radość przechodzi w zadowolenie, czyli traci na intensywności. Choć gdy wzbudzane są wspomnienia z okresu sprzed udomowienia technologii, to wtedy cały okres zaspokajania potrzeb przy ich pomocy jest określany jako: szczęście, raj, niebo, rozkosz. Ponadto, odczuwane są radość ze zdobycia trudnodostępnego dobra w gospodarce niedoboru. Duma z udomowienia technologii, zwłaszcza jeśli udało się to dopiero nielicznym i jest wynikiem oraz świadectwem zasług czy starań podmiotu.

Proszę paniqa, każdy się cieszyl. Bo te pralki nie byly tak $w$ sklepie, że można byto iść kupić. One byly na talony. A że ja bytam dość dobrym pracownikiem u siebie, za którą pracę dostałam medal z legitymacją, z wszystkim, także wie pani, to ja dostatam talon, z tym talonem poszlam kupić pralkę. (Waw11P2)

W przypadku technologii udamawianych dla przyjemności, doznawana jest oczywiście przyjemność, co pokazałam w pierwszym podrozdziale. Towarzyszą jej więc te same emocje, które towarzyszą przyjemności po zaspokojeniu potrzeby: radość, szczęście, duma, potem zadowolenie. Natomiast w przypadku technologii interaktywnych, podczas użytkowania których wytwarza się zaangażowanie w obiekt, pojawia się fascynacja. To fascynacja jest emocją odczuwaną, gdy rozmówców pewna praktyka „wciąga” i „idą za głosem serca”.

Tak, ta technika procesorowa, komputery, największy wphyw na mnie wywarly. Bo ja się zawsze fascynowatem komputerami, robotyka... (Waw4P5)

Emocje w trakcie konsumpcji, zwiq̨zane z aspektem nowości kategorii przedmiotu

W przypadku gdy udomowiona została technologia, która należała do nowej kategorii, od niedawna obecnej w otoczeniu społecznym rozmówców, to jej pozyskanie i użytkowanie wyzwalało emocje poruszające całe 
jestestwo: radość, wzruszenie, przeżycie - łączące w sobie konglomerat wielu emocji radości, szczęścia, zaskoczenia, zachwytu, ekscytacji, dumy.

Ogromne przeżycie, jak przestawić swoje życie o tyle, wie pani. To zmienito tyle, że mnie jako matce było tatwiej. (Waw12P1)

Zarówno w ramach dyskursu postępu, jaki w modelu nowoczesnego hedonizmu udomowiona nowość wzbudzała silne pozytywne emocje, obydwa te modele emocjonalności kontrastują z lękiem i nieufnością wobec nowości, charakterystycznymi dla społeczeństw tradycyjnych. Technologie zaspokajające potrzeby, gdy tracą swój aspekt nowości, stają się przezroczyste i nie wzbudzają emocji (por. powyżej). Przedmioty pragnień podobnie, wywołują obojętność, stawiane właściwie na równi z technologiami funkcjonalnymi:

Także może nie domowe sprzęty mnie podniecają, czy tam telewizory, ale to [trenażer] akurat super. (Waw1P5)

Przemiany emocjonalności w procesie rewolucji konsumpcyjnej. Podsumowanie

Moim celem było odpowiedzieć na pytanie, czy w procesie rewolucji konsumpcyjnej w środowisku wielkomiejskim w warunkach polskich miały miejsce przemiany emocjonalności. Termin „przemiany” zoperacjonalizowałam jako różnice pomiędzy pokoleniami historycznymi. Na podstawie literatury przedmiotu wyodrębniłam dwa typy emocjonalności emocjonalność wpisana wdyskurs postępu i nowoczesny hedonizm, odpowiadające Ja modernistycznemu i J a romantycznemu. Na bazie analizy materiału scharakteryzowałam funkcjonowanie tych dwu modeli emocjonalności w badanej grupie. Następnie sprawdziłam, czy w grupie badanej istnieją różnice między pokoleniami w występowaniu cech obu typów. Badałam emocje kierowane wobec udamawianych technologii, 
ponieważ są to obiekty wzbudzające emocje w ramach zarówno dyskursu postępu, jak i nowoczesnego hedonizmu. W ramach dyskursu postępu wkraczające technologie są symbolem samego postępu, wartościowane są intensywnie pozytywnie. Natomiast dla nowoczesnego hedonizmu wkraczające technologie są kwintesencją nowego pożądanego dobra.

Nowoczesny hedonizm w rozwiniętej postaci dominuje u rozmówców z pokolenia transformacji (P5). Wśród rozmówców zestarszych pokoleń historycznych jest obecne podejmowanie praktyk dla wzbudzenia emocji, jednak bardzo sporadycznie jest wyrażane pożądanie (w P4) i przyjemnościowe zaangażowanie w obiekt (w P3). Dyskurs postępu dominuje w najstarszych pokoleniach (P1), pokoleniu odwilży (P2) oraz pokoleniu małej reformy (P3). J eśli porównamy to z danymi na temat liczby fragmentów zawierających odniesienia do emocji oraz liczby wymienianych emocji, to okazuje się, że jest pełna zgodność. Przedstawiciele P1, P2 i P3 w podobnym stopniu i rzadziej niż młodsze pokolenia mówią o emocjach, wymieniają też zdecydowanie mniej emocji. Z kolei P5 najczęściej mówi o emocjach i wymienia najwięcej emocji. P4 zajmuje rangę pośrednią dla obu wymiarów.

Wyniki te wskazują, że na przestrzeni pokoleń historycznych w grupie badanej nowoczesny hedonizm wyparł typ emocjonalności charakterystyczny dla dyskursu postępu. Próbując wyabstrahować najważniejsze przemiany emocjonalności, można wskazać: wzrost emocjonalności, czyli częstsze wyrażanie emocji oraz większą liczbę i zróżnicowanie wyrażanych emocji; wyrażanie emocji pożądania; angażowanie się w praktyki dla wzbudzenia - poruszenia emocji. Tezy te wynikają z analizy materiału zebranego w małym wycinku wielkomiejskiego życia społecznego i stanowią empiryczną ilustrację dla teorii podkreślających rolę przemian emocjonalności w procesie psychogenezy nowoczesnego podmiotu (Zalewska 2014; Campbell 1987; Marody 2014). 
Bibliografia

Ahmed, S. (2014). The Cultural Politics of Emotion. Edynburg: Edinburgh University Press.

Appadurai, A. (2005). Nowoczesność bez granic. Kulturowe wymiary globalizacji. Kraków: Universitas.

Campbell, C. (1987). The Romantic Ethic and the Spirit of Modern Consumerism. Oxford: Blackwell Publishers.

Cowan, RS. (1976). The 'Industrial Revolution' in the Home: Household technology and social change in the $20^{\text {th }}$ century. Technology and Culture No. 17(1), 1-23.

Czerwiński, M. (1969). Przemiany obyczaju. Warszawa: PIW.

Davies, N. (2005). God's Playground. A History of Poland, vol. II. Oxford: Oxford University Press.

De Grazia, V. (2005). Irresistible Empire: America's Advance through Twentieth-Century Europe. Cambridge, MA: Harvard University Press.

Dyczewski, L. (1982). Kontynuacja i zmiana w stylach życia polskiego społeczeństwa. Roczniki nauk spolecznych $\mathrm{nr}$ 10, 231-246.

Elias, N. (2011). O procesie cywilizacji. Analizy socjo- $i$ psychogenetyczne. Warszawa: WAB.

Foucault, M. (1977). Archeologia wiedzy. Warszawa: PIW.

Geertz, C. (2003). Opis gęsty - w stronę interpretatywnej teorii kultury. [w]: Badanie kultury. Elementy teorii antropologicznej. (red.) Kempny M., Nowicka E., Warszawa: Wydawnictwo Naukowe PWN, 35-58.

Gergen, K. (2009). Nasycone Ja. Dylematy tożsamości w życiu wspótczesnym. Warszawa: Wydawnictwo Naukowe PWN.

GUS (1956). Rocznik Statystyczny 1955. Warszawa: GUS.

Haranne M., Siciński, A. (1987). Changes of Life Styles in Finland and Poland.[w]: Ways of Life in Finland and Poland. Comparative Studies on Urban Populations. (Eds.) Roos J-P., Siciński A. Aldershot: Avebury, 12-35. 
Hand, M., Shove, E. (2007). Condensing practices: Ways of living with a freezer. Journal of Consumer Culture No. 7(1), 79-104.

Hochschild, A.R. (2009). Zarzadzanie emocjami. Komercjalizacja ludzkich uczuć. Warszawa: Wydawnictwo Naukowe PWN.

Illouz, E. (2010). Uczucia $w$ dobie kapitalizmu. Warszawa: Oficyna Naukowa.

J aworska, J . (2008). Cywilizacja 'Przekroju'. Misja obyczajowa w magazynie ilustrowanym. Warszawa: Wydawnictwa Uniwersytetu Warszawskiego.

Komorowski, Ł. (2018). Proces elektryfikacji polskiej wsi - ujęcie historyczne i terytorialne. Roczniki Naukowe Stowarzyszenia Ekonomistów Rolnictwa i Agrobiznesu nr XX(4), 85-90. doi: 10.5604/01.3001.0012.2949

Knorr-Cetina, K. (1997). Sociality with Objects. Social Relations in Postsocial Knowledge Societies. Theory, Culture \& Society No 14(4), 1-30.

Kurz, I. (2008). Konsumpcja: 'coca-cola to jest to'! [w]: Obyczaje polskie. Wiek XX w krótkich hastach. (red.) Szpakowska M. Warszawa: WAB, 145-157.

Marody, M. (2014). Jednostka po nowoczesności. Perspektywa socjologiczna. Warszawa: Scholar.

McKendrick, N., Brewer, J., Plumb, J.H. (1982). The Birth of a Consumer Society: The Commercialization of eighteen Century England. Bloomington, IN: Indiana University Press.

Okólski, M. (2002). Przemiany ludnościowe $w$ Polsce $w$ perspektywie minionego stulecia. [w]: Wymiary życia społecznego. Polska na przetomie XX i XXI wieku. (red.) Marody M. Warszawa: Scholar, 26-68.

Olcoń-Kubicka, M. (2009). Indywidualizacja a nowe formy wspólnotowości. Warszawa: Scholar.

Pohoski, M. (1963). Migracje ze wsi do miast: studium wychodźstwa w latach 1945-1957. Warszawa: PWE.

Pleskot, P. (2007). Wielki mały ekran. Telewizja a codzienność Polaków w latach sześćdziesiątych. Warszawa: Trio. 
Sawicka, M., Sikorska, M. (2020). Struggling with Emotions in Times of Social Change: Control Restoring Operations in the Workplace and the Family. Polish Sociological Review No. 212(4), 411-424. https:// doi.org/ 10.26412/ psr212.02.

Schatzki, T. (2001). Introduction: Practice Theory. The Practice Turn in Contemporary Theory. [w]: (Eds.) Schatzki, T., Knorr-Cetina, K., Von Savigny, E. Londyn: Routledge, 10-23.

Schmidt, F., Olcoń-Kubicka, M., Żadkowska, M., J asińska, J ., Halawa, M. (2018). W stronę socjologii pary: propozycja paradygmatu teoretyczno-badawczego. Studia Socjologiczne, nr 3(230), 11-39.

Sieradzki, P. (2007). Teoria „społeczeństwa doznan” („erlebnisgesellschaft”) u Gerharda Schulze. Acta Universitatis Lodziensis, Folia Sociologica nr 32, 105-116.

Silverstone, R. (1993). Time, information and communication technologies and the household. Time \& Society No. 2(3), 283-311.

Skowrońska, M. (2020). Why Do We Have To Turn On This Washing Machine? The Processes of Domesticating Household Technology Situations of Resistance. Etnografia Polska, nr LXIV(1-2), 197-218. Szatur-J aworska, B. (2000). Ludzie starzy i starość w polityce społecznej. Warszawa: Oficyna Wydawnicza ASPRA-J R.

Sztompka, P. (2010). Socjologia zmian społecznych. Kraków: Wydawnictwo Znak.

Świda-Ziemba, H. (1995). Wartości egzystencjalne mtodzieży lat dziewięćdziesiątych. Warszawa: Wydawnictwa Uniwersytetu Warszawskiego.

Świda-Ziemba, H. (2010). Młodzież PRL. Portrety pokoleń w kontekście historii. Kraków: Wydawnictwo Literackie.

Turner, J .H., Stets, J .E. (2009). Socjologia emocji. Warszawa: Wydawnictwo Naukowe PWN.

Weber, M. (2011). Etyka protestancka a duch kapitalizmu. Warszawa: Wydawnictwa Uniwersytetu Warszawskiego. 
Zalewska, J . (2011). Nowe przedmioty a przemiany praktyk społecznych $w$ doświadczeniu ludzi starych. [w]: Ku socjologii starości. Starzenie się w biegu życia jednostki. (red.) Mucha J ., Krzyżowski J . Kraków: Wydawnictwo AGH, 201-226.

Zalewska, J . (2013). Rewolucja konsumpcyjna: od gospodarki naturalnej do społeczeństwa mody. [w]: Krótkie wykłady z socjologii. Kategorie, problemy subdyscypliny, Vol. II. (red.) Firkowska-Mankiewicz A., Kanash T., Tarkowska E., Warszawa: Wydawnictwo APS, 139-151.

Zalewska J . (2014). Wpływ mody na kształtowanie się emocjonalnego podmiotu. Czy i kiedy dokonało się „zerwanie pokoleniowe”? [w]: Od obyczaju do mody: przemiany życia codziennego. (red) Zalewska J ., Cobel-Tokarska M. Warszawa: Wydawnictwo APS, 417-428.

Zalewska, J . (2015). Rewolucja konsumpcyjna i kształtowanie się podmiotu emocjonalnego w perspektywie Norberta Eliasa. Kultura i Społeczeństwo $\mathrm{nr}$ 1, 115-136.

Zalewska, J . (2017). Consumer revolution in People’s Poland: Technologies in everyday life and the negotiation between custom and fashion (1945-1980), Journal of Consumer Culture No. 17(2), 321-339. DOI:10.1177/ 1469540515595125.

Zalewska, J . (2018). Podłączeni pod społeczeństwo mody: udomawianie telewizora a kształtowanie się mody w Polsce Ludowej. Analiza materiałów z badań nad stylami życia Andrzeja Sicińskiego (197882). Przegląd Socjologii Jakościowej, nr 14(4), 190-218. DOI:10.18778/1733- 8069.14.4.10.

Zalewska, J . (2020). And It All Happened in Our Lifetime - Progress and Comfort: The Meaning of Technology Domestication Practices. Etnografia Polska nr LXIV(1-2), 219-244.

Zalewska J ., Skowrońska M. (2020). Technologies in the Practices of Daily Life: Introduction. Etnografia Polska nr LXIV(1-2), 193-196. 
Zalewska J., J ewdokimow M. [w druku]. The Wall Unit: State Policy and the Emergence of Fashion in People's Poland. Journal of Consumer Culture. 